Vietnam Academy of Science and Technology
Vietnam Journal of Earth Sciences
http://www.vjs.ac.vn/index.php/jse

\title{
Characteristics of soil acidification of haplic Acrisols on ancient alluvial deposits under intensive cassava cultiva- tion in Chau Thanh district, Tay Ninh province
}

\author{
Nguyen Tho* ${ }^{1}$, Nguyen Thi Hoa ${ }^{2}$ \\ ${ }^{1}$ Ho Chi Minh City Institute of Resources Geography, 01 Mac Dinh Chi, District 1, Ho Chi Minh City \\ ${ }^{2}$ Saigon University, 273 An Duong Vuong, Disrict 5, Ho Chi Minh City
}

Received 21 January 2017. Accepted 21 March 2017

\begin{abstract}
This paper clarified the characteristics of soil acidification of haplic Acrisols on ancient alluvial deposit under intensive cassava cultivation in Chau Thanh district, Tay Ninh province, Southeastern Vietnam. Soils were sampled at 3 intervals $(0-20,20-40,40-60 \mathrm{~cm}$ in depth) in 12 sites of intensive cassava cultivation and geochemical parameters related to soil acidity were analysed. The haplic Acrisols under intensive cassava cultivation showed quite high levels of active and exchange acidity $\left(\mathrm{pH}_{\mathrm{H} 2 \mathrm{O}} 4.40 \pm 0.11, \mathrm{pH}_{\mathrm{KCl}} 3.98 \pm 0.07\right)$. The hydrolytic acidity and $\mathrm{Al}$ saturation level were also high (respectively $4.52 \pm 0.37 \mathrm{meq} / 100 \mathrm{~g}$ and $57.64 \pm 6.41 \%$ ) while the exchange alkali and alkaline earth cations were very low $\left(\mathrm{Ca}^{2+} 0.76 \pm 0.25 \mathrm{meq} / 100 \mathrm{~g}, \mathrm{Mg}^{2+} 0.88 \pm 0.85 \mathrm{meq} / 100 \mathrm{~g}, \mathrm{~K}^{+} 0.16 \pm 0.06 \mathrm{meq} / 100 \mathrm{~g}\right.$ in the top layer). This exhibited a limit for mineral nutrients and risk of Al toxicity to cassava plants. If the area for intensive cassava cultivation is expanded and the high-yield cassava varieties are applied, the risk of soil acidification will be expected to be highly serious. It is needed to clarify the processes involved and to establish measures to reduce soil acidification and stabilize cassava production in the study area and Tay Ninh province.
\end{abstract}

Keywords: soil acidification, nutrient, haplic Acrisols, Tay Ninh, cassava.

(C)2017 Vietnam Academy of Science and Technology

\section{Introduction}

Soil acidification as a result of intensive cassava cultivation in upland areas is an issue of global concern. Intensive cassava cultivation has been proved to cause the depletion or nutrient imbalance in soils in Africa (Kenya, Uganda, Cameroon) and Southeast Asia (Thailand, Cambodia) (Araki, Sarr, 2013; CIAT, 2007; Francis et al., 2013; Noble et al., 2004; Sarr et al., 2013). The major causes of

"Corresponding author, Email: ntho@hcmig.vast.vn this are surface erosion and run-off, leaching, and harvest of biomass (Howeler, 1996; CIAT, 2007). Nutrients (particularly $\mathrm{Ca}$ and N) removed from soils are highly intensive if stems and leaves of cassava are also harvested (Howeler, 2001). The final consequence is the mass leaching of bases and accumulation of acidic components into the soils, leading to an overall soil acidification.

In Vietnam, cassava has largely been consumed in the domestic market and is one of the main crops for export (Pham Van Bien et al., 2002; Le Huy Ham et al., 2016). It pro- 
vides low yield in general, partly due to the fact that it is often planted on slope soils, which are heavily eroded and nutrientdepleted (Howeler, Phien, 2000). Nutrient imbalance and nutrient loss in upland soils under intensive cassava cultivation areas have been reported, for example, Nguyen Tu Siem, Thai Phien (1993) and Sat, Deturck (1998). This issue is very serious in the Southeast of Vietnam, even after 2 years of cultivation (Nguyen Tu Siem, Thai Phien, 1993).

Tay Ninh province is located in the Southeast of Vietnam and covers an area of $4.035,45 \mathrm{~km}^{2}$, in which Acrisols accounts for $84,13 \%$. This soil group in Tay Ninh composes of three soil units, consisting of Haplic Acrisols (230,323 ha), Stagni-Plinthic Acrisols (50,526 ha) and Gleyic Acrisols (49,184 ha) (Sub-NIAPP, 2004). Due to the natural conditions and market demand, the area for cassava cultivation has been on the increase in Tay Ninh province, particularly in Tan Bien, Tan Chau, Chau Thanh and Duong Minh Chau districts. According to the provincial planning for agriculture, the area for cassava cultivation in 2020 will rank $4^{\text {th }}$ and occupy 29,000 ha, after sugarcane $(30,000$ ha), rubber $(87,000$ ha), and rice (125,000 ha) (Tay Ninh Provincial People's Committee, 2012).

The haplic Acrisols on ancient alluvial deposit in Tay Ninh province are light-textured, highly eroded, and acidic soils. The rapid development of intensive cassava production

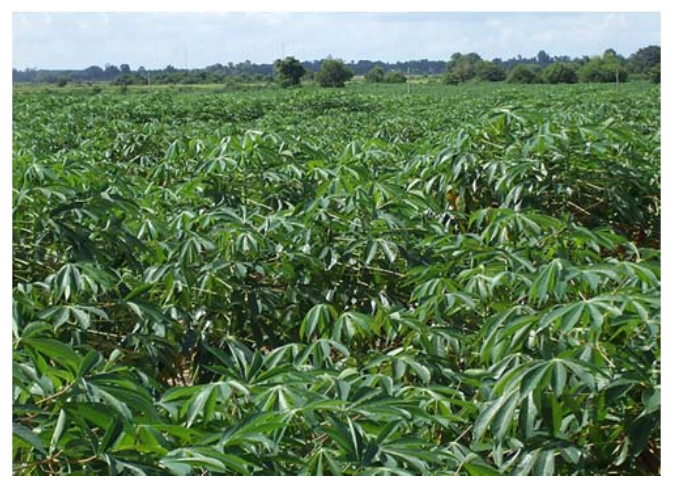

(a) might increase the risk of acidification of these soils. Up to present, there has been no study dealing with factors and processes relating to soil acidification due to cassava cultivation in Tay Ninh province. To build up grounds for the deeper understanding on soil acidification, this paper aims to examine the characteristics of soil acidification of haplic Acrisols on ancient alluvial deposited under cassava cultivation areas in Chau Thanh district.

\section{Materials and methods}

\subsection{Study area}

Chau Thanh district $\left(571.25 \mathrm{~km}^{2}\right)$ is located at the South-West border of Tay Ninh province, sharing the $48 \mathrm{~km}$ borderline with Svay Rieng province of Cambodia. There is a source of all-year-round freshwater supply, making the area highly favorable for agricultural development. Haplic Acrisols in this area mainly distribute in mounds or in elevated foot slopes.

Cassava is cultivated on a wide range of topography of the district (Figure 1a). Land areas for cultivating cassava was previously used to grow other crops, such as rice, tobacco, cashew, or cassava intercropped with other vegetables. This conversion is taken place due to a higher economic return of cassava in comparison to the former crops. Following harvest, farmers often shred the stems and bury it with the leaves into the soil surface layers (Figure 1b).

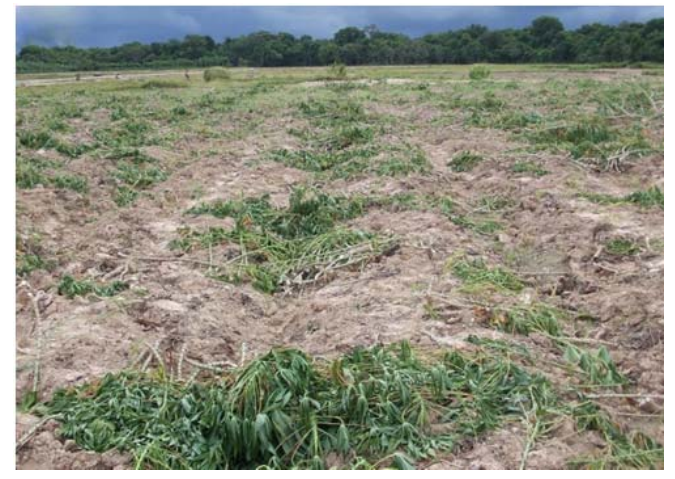

(b)

Figure 1. Intensive cassava cultivation in Chau Thanh district 


\subsection{Soil sampling and analysis}

Soils were sampled at 12 sites (Figure 2) in August 2015 based on the soil map of Tay Ninh province, scale 1:100,000) (Sub-NIAPP, 2004). At each sampling site, samples were collected at 3 depth intervals $(0-20 \mathrm{~cm}, 20-40$ $\mathrm{cm}$, and 40-60 $\mathrm{cm}$ in depth) after removing the topsoils generated by raised beds in 3 profiles within an area of about $400 \mathrm{~m}^{2}$. Samples of the same depths in these 3 profiles were mixed to form a composite sample for analysis. In total, there were 36 soil samples to be analysed.

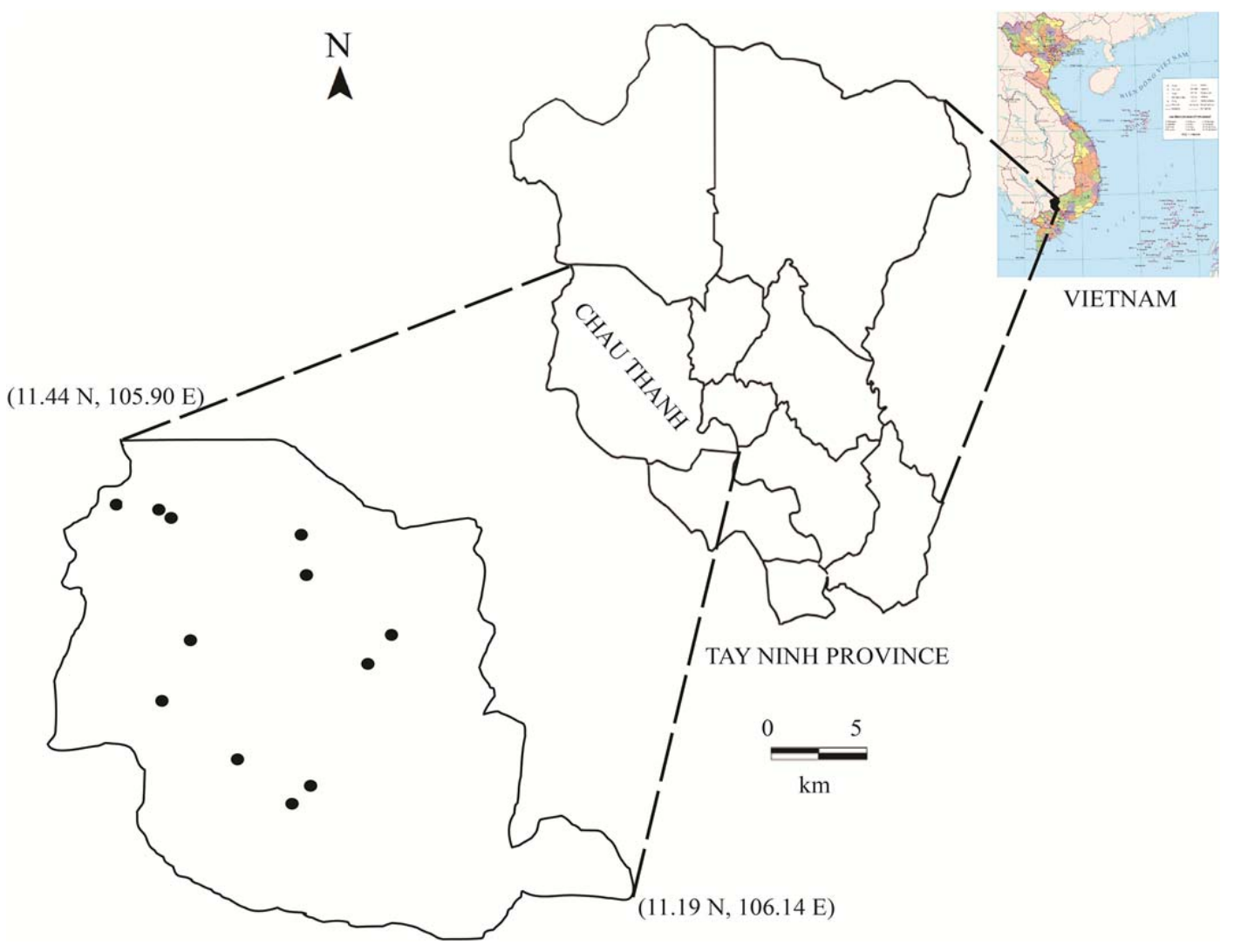

Figure 2. Chau Thanh district and the sampling sites

In the laboratory, samples were air-dried, ground and passed through a $2 \mathrm{~mm}$ sieve, then were analysed at Ho Chi Minh City Institute of Resources Geography and Ho Chi Minh City University of Science. The parameters, methods, and calculations are as follows (1) $\mathrm{pH}_{\mathrm{H} 2 \mathrm{O}}$ : by $\mathrm{pH}$-meter after extracted with distilled water (1/2.5); (2) $\mathrm{pH}_{\mathrm{KCl}}$ : by $\mathrm{pH}$-meter after extracted with $\mathrm{KCl} 1 \mathrm{~N}(1 / 5)$; (3) exchange acidity: extracted with $\mathrm{KCl} 1 \mathrm{~N}$, titrate the filtered solution by $\mathrm{NaOH} 0.02 \mathrm{~N}$ with phenolphthalein as color indicator to light pink color; (4) exchange $\mathrm{H}^{+}$ and $\mathrm{Al}^{3+}$ : titrate the filtered solution after extracted with $\mathrm{KCl} 1 \mathrm{~N}$ with $\mathrm{NaOH} 0.02 \mathrm{~N}$ (phenolphthalein as indicator) to light pink color (after precipitating $\mathrm{Al}^{3+}$ by $\mathrm{NaF} 3,5 \%$ ) to calculate exchange $\mathrm{H}^{+}$, then exchange $\mathrm{Al}^{3+}$ is calculated by subtracting exchange $\mathrm{H}^{+}$from the exchange acidity; (5) hydrolytic acidity: extracted with $\mathrm{CH}_{3} \mathrm{COONa} 1 \mathrm{M}(\mathrm{pH} 8)$ and titrated with $\mathrm{NaOH} 0.1 \mathrm{~N}$ with phenolphthalein as color indicator to light pink color; (6) Exchange alkali 
and alkaline earth cations $\left(\mathrm{Ca}^{2+}, \mathrm{Mg}^{2+}, \mathrm{K}^{+}\right)$: extracted with $\mathrm{CH}_{3} \mathrm{COONH}_{4} 1 \mathrm{~N}(\mathrm{pH} 7)$ and measured by Atomic Absorption Spectrometry; (7) effective CEC (eCEC) = sum of exchange base cations + exchange acidity; (8) Base saturation $=$ (sum of exchange base cations $\times$ 100)/eCEC; (9) $\mathrm{Al}$ saturation $=\left(\right.$ exchange $\mathrm{Al}^{3+}$ $\times 100) / \mathrm{eCEC}$; and (10) $\Delta \mathrm{pH}=\mathrm{pH}_{\mathrm{KCl}}-\mathrm{pH}_{\mathrm{H} 2 \mathrm{O}}$ (Mekaru, Uehara, 1972; Rowell, 1994; Soils and Fertilizers Research Institute 1998).

\subsection{Statistical analysis}

Descriptive statistics, t-test (dependent samples) and Repeated Measured ANOVA were applied. The independent variable is "depth" with 3 levels $(0-20 \mathrm{~cm}, 20-40 \mathrm{~cm}, 40-$ $60 \mathrm{~cm})$. Dependent variables are geochemical parameters. A Pearson correlation matrix was calculated to examine the correlated levels among geochemical parameters. The $95 \%$ confidence interval of the dependent variables are set as Mean $\pm 1.96 * \mathrm{SE}$ (standard error). All of the statistical tests are performed on the Statistica package, version 7.0 (StatSoft, Inc., 2001).

\section{Results}

The haplic Acrisols in the study area were characterized by low $\mathrm{pH}, \Delta \mathrm{pH}<0$, elevated exchange acidity and $\mathrm{Al}^{3+}$, and low eCEC (Table 1). While $\mathrm{pH}_{\mathrm{H} 2 \mathrm{O}}$ showed little variations with depths, $\mathrm{pH}_{\mathrm{KCl}}$ at $40-60 \mathrm{~cm}$ was significantly lower $(p<0.05)$ in comparison to the topsoil (Figure 3), being similar to the trend of exchange acidity, exchange $\mathrm{Al}^{3+}$ and sum of exchange base cations.

Table 1. The geochemical parameters related to soil acidity of Haplic Acrisols on ancient alluvial deposit in the study area

\begin{tabular}{|c|c|c|c|c|c|}
\hline Parameter & Unit & Mean & Minimum & Maximum & $1.96 * \mathrm{SE}$ \\
\hline $\mathrm{pH}_{\mathrm{H} 2 \mathrm{O}}$ & - & 4.40 & 3.97 & 5.24 & 0.11 \\
\hline $\mathrm{pH}_{\mathrm{KCl}}$ & - & 3.98 & 3.68 & 4.64 & 0.07 \\
\hline$\Delta \mathrm{pH}$ & - & -0.42 & -1.13 & -0.05 & 0.08 \\
\hline Exchange acidity & $\mathrm{meq} / 100 \mathrm{~g}$ & 1.7 & 0.68 & 3.33 & 0.21 \\
\hline Exchange $\mathrm{H}^{+}$ & $\mathrm{meq} / 100 \mathrm{~g}$ & 0.08 & 0.05 & 0.09 & 0.01 \\
\hline Exchange $\mathrm{Al}^{3+}$ & $\mathrm{meq} / 100 \mathrm{~g}$ & 1.63 & 0.63 & 3.24 & 0.2 \\
\hline Exchange $\mathrm{Ca}^{2+}$ & $\mathrm{meq} / 100 \mathrm{~g}$ & 0.65 & 0.13 & 1.7 & 0.12 \\
\hline Exchange $\mathrm{Mg}^{2+}$ & $\mathrm{meq} / 100 \mathrm{~g}$ & 0.58 & 0.02 & 5.11 & 0.34 \\
\hline Exchange $\mathrm{K}^{+}$ & meq/100g & 0.14 & 0.05 & 0.61 & 0.04 \\
\hline Sum of exchange base cations & $\mathrm{meq} / 100 \mathrm{~g}$ & 1.36 & 0.23 & 6.66 & 0.44 \\
\hline eCEC & $\mathrm{meq} / 100 \mathrm{~g}$ & 3.07 & 1.54 & 7.54 & 0.4 \\
\hline Base saturation (BS) & $\%$ & 39.55 & 13.48 & 88.24 & 6.69 \\
\hline $\mathrm{Al}$ in exchange acidity & $\%$ & 95.22 & 90.82 & 97.81 & 0.51 \\
\hline Al saturation & $\%$ & 57.64 & 11.09 & 82.21 & 6.41 \\
\hline Hydrolytic acidity & $\mathrm{meq} / 100 \mathrm{~g}$ & 4.52 & 2.38 & 6.58 & 0.37 \\
\hline
\end{tabular}

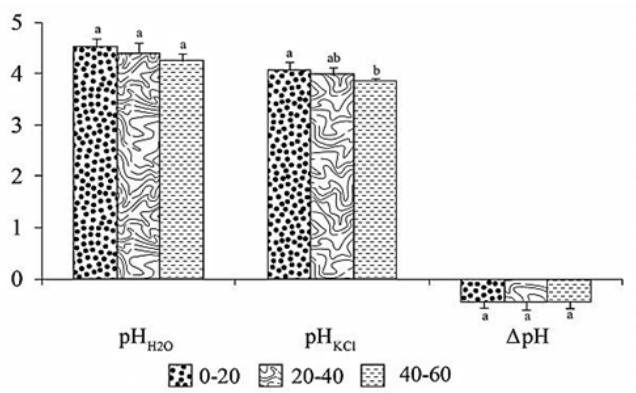

Figure 3. Variations of $\mathrm{pH}_{\mathrm{H} 2 \mathrm{O}}, \mathrm{pH}_{\mathrm{KCl}}$, and $\Delta \mathrm{pH}$ with depths
The mean $\mathrm{pH}_{\mathrm{H} 2 \mathrm{O}}$ was $4.40 \pm 0.11$, being higher than $\mathrm{pH}_{\mathrm{KCl}}$ (mean 3.98 \pm 0.07 ) for all depth intervals $(\mathrm{p}<0.001)$. On average, $\Delta \mathrm{pH}$ was $-0.42 \pm 0.08 \mathrm{pH}$ unit (Figure 3). The relationship between $\mathrm{pH}_{\mathrm{H} 2 \mathrm{O}}$ and $\Delta \mathrm{pH}$ was negative, by which soils reached to the point of zero charge when $\Delta \mathrm{pH}=0$, corresponding to a $\mathrm{pH}_{\mathrm{H} 2 \mathrm{O}}$ of 3.96 (Figure 4). The exchange acidity and $\mathrm{Al}^{3+}$ tend to increase with depths, while the sum of exchange base cations showed an opposite trend (Figure 5). 


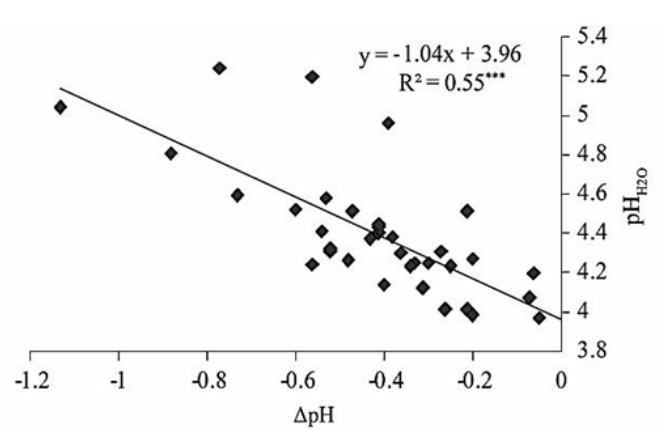

Figure 4. Relationship between $\mathrm{pH}_{\mathrm{H} 2 \mathrm{O}}$ and $\Delta \mathrm{pH}$

The hydrolytic acidity was high, ranging from $2.38-6.58 \mathrm{meq} / 100 \mathrm{~g}$ with an overall mean of $4.52 \pm 0.37 \mathrm{meq} / 100 \mathrm{~g}$ (Table 1$)$. The hydrolytic acidity slightly varied with depth (Figure 6a) and positively correlated with exchange acidity (Figure 6b). On average, values of hydrolytic acidity are $2.82 \pm 0.28 \mathrm{meq} / 100 \mathrm{~g}$ higher than that of exchange acidity.

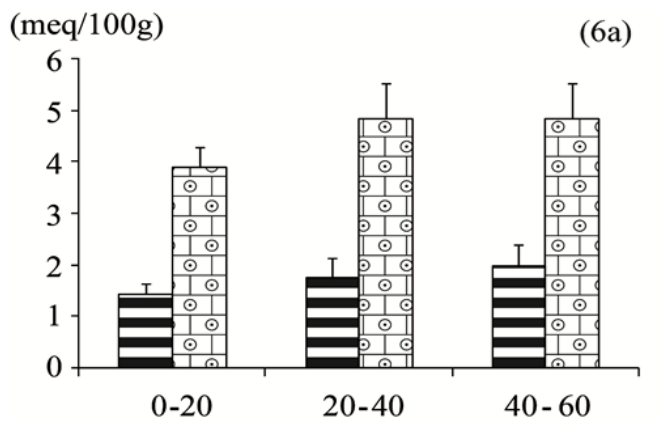

Exchange acidity 因 Hydrolytic acidity

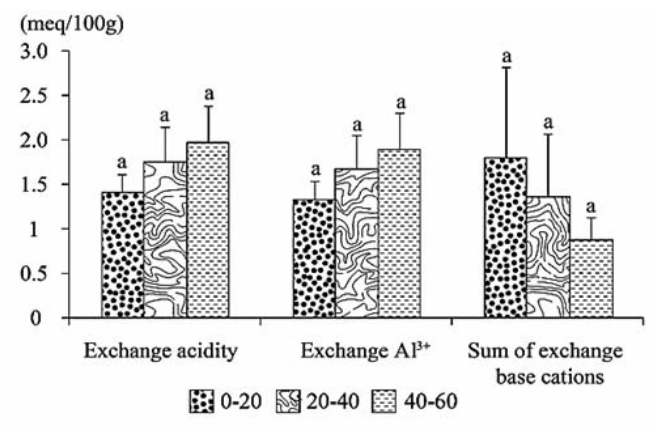

Figure 5. Mean $\pm 1.96 \mathrm{SE}$ of exchange acidity, exchange $\mathrm{Al}^{3+}$ and sum of exchange base cations of each soil layer

Soil base saturation and mineral nutrients for cassava (alkali and alkaline earth cations) were very poor (Table 1 ). In the top layer, contents of exchange $\mathrm{Ca}^{2+}, \mathrm{Mg}^{2+}$ and $\mathrm{K}^{+}$were very low, $0.76 \pm 0.25 \mathrm{meq} / 100 \mathrm{~g}, 0.88 \pm 0.85$ $\mathrm{meq} / 100 \mathrm{~g}$ and $0.16 \pm 0.06 \mathrm{meq} / 100 \mathrm{~g}$, respectively. $\mathrm{Ca}^{2+}$ and $\mathrm{Mg}^{2+}$ concentrations tend to reduce with depth (Figure 7).

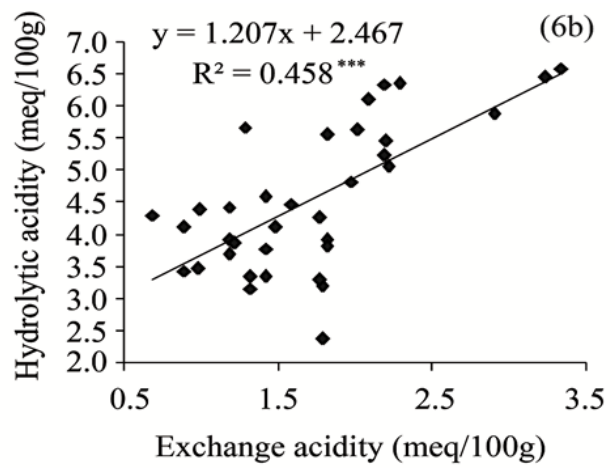

Figure 6. Mean $\pm 1.96 \mathrm{SE}$ of exchange acidity and hydrolytic acidity of each soil layer and relationship between exchange acidity and hydrolytic acidity

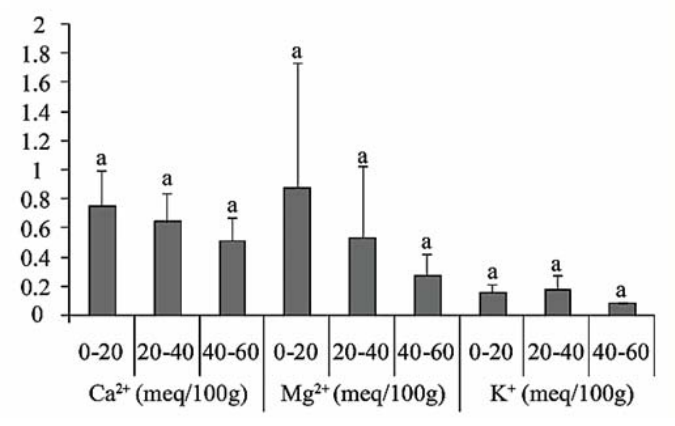

$\leftarrow$ Figure 7. Mean $\pm 1.96 \mathrm{SE}$ of alkali and alkaline earth cations of each soil layer

\section{Discussion}

\subsection{Active and exchange acidity}

According to the classification of soil acidity based on $\mathrm{pH}_{\mathrm{H} 2 \mathrm{O}}$ (Rengel, 2005), haplic Acrisols in the study area are categorized from moderately acidic $\left(\mathrm{pH}_{\mathrm{H} 2 \mathrm{O}}\right.$ 4.5-5.5) to very acidic $\left(\mathrm{pH}_{\mathrm{H} 2 \mathrm{O}} 3.5-4.5\right)$, similar to Acrisols in 
Tay Ninh province (Sub-NIAPP, 2004; Le Cong Nong, 2010).

$\Delta \mathrm{pH}<0$ (Figure 3) indicated that the exchange surface of soil particles (mostly from organic matter and clay minerals) contained a net negative charge, leading to a tendency to adsorb cations from the soil solution. According to Zołotajkin et al. (2011), $\Delta \mathrm{pH}$ is dependent on the amount of soil organic matter. When $\mathrm{pH}_{\mathrm{H} 2 \mathrm{O}}$ dropped to values lower than
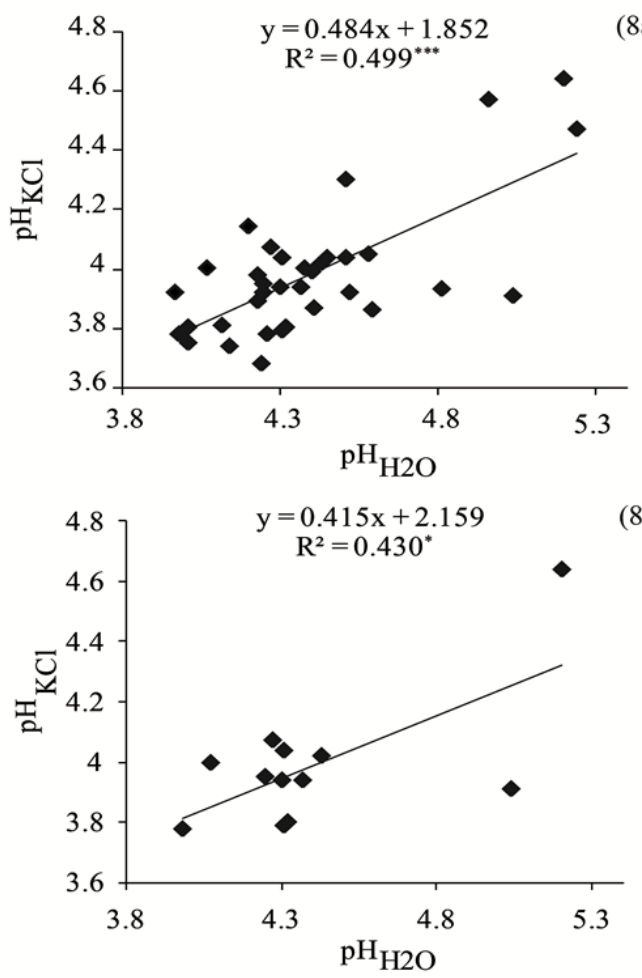

3.96 (soils having $\Delta \mathrm{pH}>0$ ), an inverse trend can be expected (Figure 4).

Over the whole profile, $\mathrm{pH}_{\mathrm{H} 2 \mathrm{O}}$ and $\mathrm{pH}_{\mathrm{KCl}}$ were linearly and positively correlated $(p<0.001)$ (Figure 8a). This correlation was quite strong in the top layer $\left(\mathrm{R}^{2}=0.556\right.$, $\mathrm{p}<0.01$ ) (Figure $8 \mathrm{~b}$ ) but became weaker at deeper layers (Figure 8c, 8d), probably due to the accumulation of $\mathrm{Al}^{3+}$ on the exchange surface of soil particles (Figure 5).
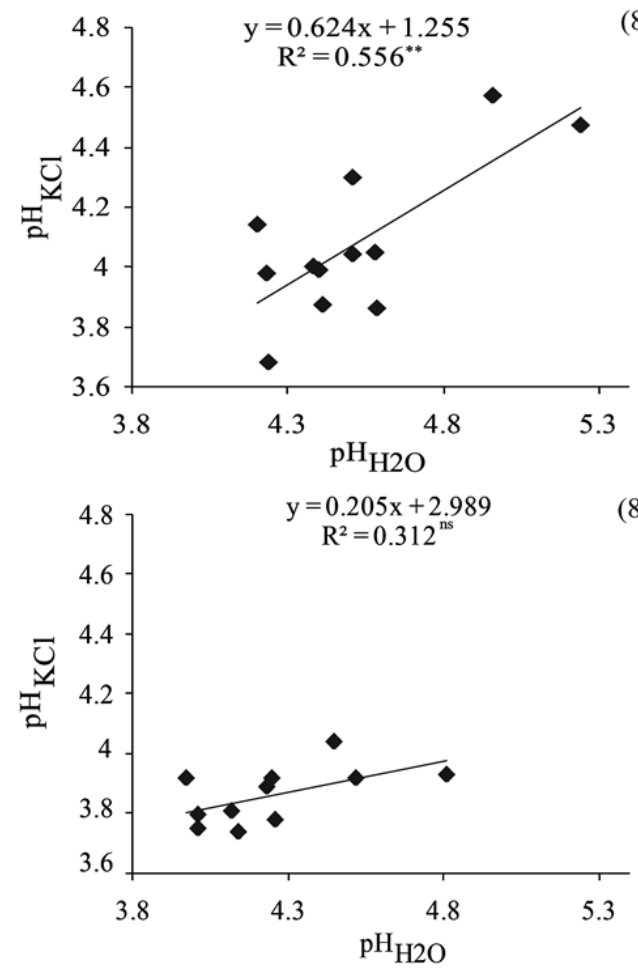

Figure 8. Relationship between $\mathrm{pH}_{\mathrm{H} 2 \mathrm{O}}$ and $\mathrm{pH}_{\mathrm{KCl}}$ over the whole soil profile (8a), the $0-20 \mathrm{~cm}$ layer (8b), the 20-40 $\mathrm{cm}$ layer (8c), and the $40-60 \mathrm{~cm}$ layer (8d)

Exchange $\mathrm{Al}^{3+}$ accounted for the majority of exchange acidity $(95.22 \pm 0.51 \%)$. This is due to the elevated $\mathrm{Al}$ content in Acrisols on ancient alluvial deposit, which was mostly in soluble forms at soil $\mathrm{pH}_{\mathrm{H} 2 \mathrm{O}}<5$ (Rengel, 2005). When extracted with $\mathrm{KCl}$, several forms of $\mathrm{Al}$ were released into the soil solution, including $\mathrm{Al}(\mathrm{OH})_{3}$ (amorphous or precipitated), dispersed alum inosilicates, networks of hydroxy- $\mathrm{Al}\left(\mathrm{AlOH}^{2+}, \mathrm{Al}(\mathrm{OH})_{2}{ }^{+}\right)$or Al-organic matter complexes (Rengel, 2005). Al saturation was quite high in the soils (57.64 $\pm 6.41 \%)$.

The $\mathrm{pH}_{\mathrm{H} 2 \mathrm{O}}$ and $\mathrm{pH}_{\mathrm{KCl}}$ of haplic Acrisols in the study area (Table 1) varied in a large range in comparison to those of the similar soil in Don Thuan commune, Trang Bang district, Tay Ninh province (respectively 4.57- 
4.90 and 3.98-4.18) (Le Cong Nong, 2010). Exchange acidity of haplic Acrisols in the study area ranged from $0.68-3.33 \mathrm{meq} / 100 \mathrm{~g}$ $(1.70 \pm 0.21 \mathrm{meq} / 100 \mathrm{~g})$, being significantly higher in comparison to Alfisols in Bihar and West Bengal of India (0.07-0.43 meq/100g) (Dolui, Mehta, 2001) and Acrisols (Rhodic Acrisols, Haplic Acrisols) in the coast of Ghana $(\leq 0.43 \mathrm{meq} / 100 \mathrm{~g})$ (Dowuona et al., 2012).

The 40-60 $\mathrm{cm}$ soil layer was not affected by root metabolism and land preparation because cassava roots reached to a shallow depth. The lower $\mathrm{pH}_{\mathrm{KCl}}$ at $40-60 \mathrm{~cm}$ layer as compared to that of the topsoil inferred that human impacts on the soil surface may not be a main driver for soil acidification in the study area.

\subsection{Hydrolytic acidity}

In haplic Acrisols in the study area, the hydrolytic acidity was higher and positively correlated with exchange acidity (Figure 6). The difference between these two kinds of acidity depends on the clay ratio and total $\mathrm{Al}$ content in the soils (Soils and Fertilizers Research Institute, 1998).

Hydrolytic acidity of Acrisols in the study area was much higher than that of haplic Luvisol in Slovakia $(1.17 \mathrm{meq} / 100 \mathrm{~g})$ (Šimanský, 2011), haplic Cambisol in Rzeszów of Poland ( $\leq 2 \mathrm{meq} / 100 \mathrm{~g}$ ) (Gasior, Puchalski, 2010), Alfisols in Bihar and West Bengal of India (0.96-3.65 meq/100g) (Dolui, Mehta, 2001) and other soils (Vertisols, Alfisols and Ultisols) in East Kalimantan of Indonesia (1.56 $\pm 0.37 \mathrm{meq} / 100 \mathrm{~g})$ (Supriyo et al., 1992). This pattern showed a high risk of acidification of haplic Acrisols under intensive casava cultivation in the study area.

\subsection{Alkali and alkaline earth cations, eCEC and base saturation}

The basic cations in soils under research were very low (Table 1). Exchange $\mathrm{Ca}^{2+}$ and $\mathrm{Mg}^{2+}$ in the topsoils of haplic Acrisols in the study area were higher than those of the similar soil in Don Thuan commune, Trang Bang district, TayNinh province (respectively 0.15 $0.55 \mathrm{meq} / 100 \mathrm{~g}$ and $0.12-0.23 \mathrm{meq} / 100 \mathrm{~g}$ ) (Le Cong Nong 2010). The eCEC values was low $(3.07 \pm 0.40 \mathrm{meq} / 100 \mathrm{~g})$, in which exchange $\mathrm{Al}^{3+}$ accounted for the majority $(57.64 \pm 6.41 \%)$. Base saturation varied in a large range (13.48-88.24\%) with a mean of $39.55 \pm 6.69 \%$ and has the tendency to decline with depth ( $>0.05)$ (Figure 9), in accordance with that of exchange $\mathrm{Al}^{3+}$ and exchange acidity (Figure 5).

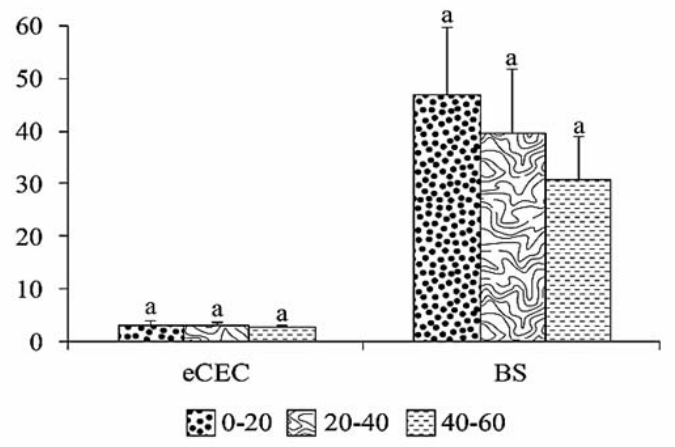

Figure 9. Depth variations of eCEC and BS

\subsection{Effects of soil acidity to cassava yield in the study area}

The $\mathrm{pH}_{\mathrm{H} 2 \mathrm{O}}$ of haplic Acrisols in the study area was lower in comparison to the optimal $\mathrm{pH}$ range for cassava $\left(\mathrm{pH}_{\mathrm{H} 2 \mathrm{O}}\right.$ 5-5.5) (Araki, Sarr, 2013). Limited contents of basic cations (Figure 7) is one of the major factors to reduce the cassava yield as demand for mineral nutrition of cassava, particularly $\mathrm{K}$, is large (Suyamto, 1998; Juo, Franzluebbers, 2003; CIAT, 2007; Sanginga, Woomer, 2009).

Al saturation levels were as high as $57.64 \%$. Although cassava can grow in soils with a $\mathrm{Al}$ saturation range from $75-80 \%$ (CIAT, 1979, 2007), cassava yield reaches to only $90 \%$ of the maxima when $\mathrm{Al}$ saturation level exceeds 40\% (Kamprath, 1980). Results demonstrated that the current soil acidity has, at least in part, posed negative impacts to the 
Nguyen Tho and Nguyen Thi Hoa/Vietnam Journal of Earth Sciences 39 (2017)

cassava yield in the study area. This assumption has been confirmed via discussion with local agricultural officials and farmers during field research.

\section{Conclusions}

The haplic Acrisols on ancient alluvial deposit under intensive cassava cultivation in the study area were acidic. Al saturation level was high whereas the exchange alkali and alkaline earth cations ( $\mathrm{Ca}, \mathrm{Mg}, \mathrm{K}$ ) were very low. This was one of the major factors to limit cassava growth and yield. If the cassava cultivation is expanded and the high-yield cassava varieties are applied, the acidification effect would be expected to be more serious. Studying the factors and processes involved and establishing measures are urgent to mitigate soil acidification in the study area.

\section{Acknowledgements}

We would like to thank the comments and suggestions from anonymous reviewers for improving the manuscript. This research is done with financial support from the Vietnam Academy of Science and Technology (VAST). The authors also wish to thank staffs of Ho Chi Minh City Institute of Resources Geography for their support in fieldwork, Ho Chi Minh City University of Science for lab analysis.

\section{References}

Araki S., Sarr P.S., 2013. The Effect of Cassava Cultivation on Soil Acidification. Center for African Area Studies, Kyoto University, Japan. A Report on Cassava Science day, IITA Cameroon February 18, 32-36.

CIAT, 1979. Annual Report for 1978.CIAT, cassava programme, Cali, Colombia, pp.A76-84. In: Hillocks R.J., Thresh J.M., Bellotti A.C. (Eds.), Cassava: Biology, Production, and Utilization. CABI Publishing, USA, ISBN 0-85199-524-1.

CIAT, 2007. Cassava Research and Development in Asia: Exploring New Opportunities for an Ancient Crop. Proceedings of the seven Regional Workshop in Bangkok, Thailand, Oct 28-Nov 1, 2002. Centro Internacional de Agricultura Tropical, pp.668.

Dolui A.K., Mehta S., 2001. Forms of acidity and lime requirement of some Alfisols.Agropedology 11, 71-77.

Dowuona G.N.N., Atwere P., Dubbin W., Nude P.M., Mutala B.E., Nartey E.K., Heck R.J., 2012. Characteristics of termite mounds and associated acrisols in the coastal savanna zone of Ghana and impact on hydraulic conductivity. Natural Science 4(7), 423-437.

Francis N.A., Constant A.M.F., Ijang T.P., Atanga N.S., Clarisse M.M.Y., Delphine M-L., Simon N.T., 2013. Effects of Cassava Cultivation on Soil Quality Indicators in the Humid Forest Zone of Cameroon. Greener Journal of Agricultural Sciences 3(6), 451-457.

Gasior J., Puchalski C., 2010. Effects of potassium on the dynamics of chemical elements in brown soil reconstructed profile. Short Communication.Polish Journal of Environmental Studies 20(3), 789-794.

Howeler R.H., 1996. Mineral nutrition of cassava. In: Craswell, E.T., C.J. Asher and J.N. O'Sullivan (Eds.), Mineral nutrient disorder of root crops in the Pacific. Proceedings of workshop, Nuku'alofa, Kingdom of Tonga, 17-20 April 1995. ACIAR Proceedings $65,110-116$.

Howeler, R.H. and Phien, T., 2000. Integrated nutrient management for more sustainable cassava production in Vietnam. Proceedings of the Vietnamese Cassava Workshop on Progress in Cassava Research and Extension in Vietnam, 16-18 March 1999, Ho Chi Minh city, Vietnam, 12-54.

Howeler RH., 2001. Nutrient Inputs and Losses in Cassava-based Cropping Systems-Examples from Vietnam and Thailand. International Workshop on Nutrient Balances for Sustainable Agricultural Production and Natural Resource Management in Southeast Asia. Bangkok, Thailand, 20-22.

Juo A.S.R., Franzluebbers K., 2003. Tropical Soils: Properties and Management for Sustainable Agriculture. Oxford University Press, UK, ISBN-10: 0-19511598-8, pp.304.

Kamprath E., 1980. Soil acidity in well-drained soils of the tropics. In: Juo A.S.R., Franzluebbers K. (Eds.), 
Vietnam Journal of Earth Sciences 39(2), 130-138

Tropical Soils: Properties and Management for Sustainable Agriculture, Oxford University Press, New York, USA, ISBN: 0-19-511598-8, pp.283.

Le Cong Nong, 2010. Study and assess the current conditions, build up the pedological map and provide solutions to reclaim soils in the Seedling Production Facility of Trang Bang -Tay Ninh. Research Institute for oil and oil plants.

Le Huy Ham, Hoang Kim, Nguyen Thi Truc Mai, Nguyen Bach Mai and Reinhardt Howeler, 2016. The cassava revolution in Vietnam. World Congress on root and tuber crops. Nanning Guangxi, China 18-22 Jan 2016.

Mekaru T., Uehara G., 1972. Anion Adsorption in Ferruginous Tropical Soils.Soil Science Society of America Journal 36(2), 296-300.

Nguyen Tu Siem, Thai Phien, 1993. Effect of cultivation for soil erosion control and fertilization to soil conservation and crop yields on sloping land. Highlight of research results on science and technology of agriculture. In: Howeler R.H, Phien T. (Eds.), Integrated nutrient management for more sustainable cassava production in Vietnam. http://ciatlibrary.ciat.cgiar.org/Articulos_Ciat/00113 Integrated_Nutrient_Management.pdf.

Noble A., Ruaysoongnern S., Sukchan S., Berthelsen S., 2004. Role of soil resource data in assessing soil acidification risk: an example from Northeast Thailand. In: Eswaran H., Vijarnsorn P., Vearasilp T., Padmanabhan E. (Eds.), Innovative techniques in soil survey: developing the foundation for a new generation of soil resource inventories and their utilization. Proceedings of a conference, Cha-am, Thailand, 21-26 March 2004, 333-340.

Pham Van Bien, Hoang Kim, Tran Ngoc Ngoan, Howeler, RH., and Wang, J.J., 2002. New developments in the cassava sector of Vietnam. www.ciat. cgiar.org/asia_cassava/.

Rengel Z., 2005. Handbook of Soil acidity. Marcel Dekker, Inc, New York, ISBN 0-8247-0890-3, pp.511.

Rowell D.L., 1994. Soil Science: Methods and Applications. Department of Soil Science, University of Reading, Pearson Education, Prentice Hall, Harlow, UK, ISBN 0-582-08784-8, pp.345.
Sanginga N., Woomer P.L., 2009. Integrated Soil fertility management in Africa: Principles, Practices and Developmental Process. Tropical Soil Biology and Fertility Institute of the International Centre for Tropical Agriculture (TSBF-CIAT), ISBN 978-929059-261-7, pp.263.

Sarr P.S., Araki S., Njukwe E., 2013. Sequential cultivation of cassava varieties in eastern Cameroon: effects on production and soil status. A Report on Cassava Science Day: Cassava performance under different soil management, IITA, Cameroon, Feb. 18, 2013, pp.4-5.

Sat C.D., Deturck P., 1998. Cassava soils and nutrient management in South Vietnam. In Howeler R.H. (Eds.), Cassava breeding, agronomy and farmer participatory research in Asia. Proc. 5th Regional Workshop, Danzhou, Hainan, China. Nov 3-8, 1996, 257-267.

Šimanský V., 2011. Chemical properties, soil structure and organic matter in different soil managements and their relationships with carbon sequestration in water-stable aggregates. Research Journal of Agricultural Science 43(4), 138-149.

Soils and Fertilizers Research Institute, 1998. Handbook for the analysis of Soil, Water, Fertilizer, and Plants. Agricultural Publishing House, 595pp.

StatSoft, Inc., 2001. STATISTICA (Data AnalysisSoftware System), Version 7.www.statsoft.com.

Sub-NIAPP, 2004. Report on Tay Ninh soil map. Ministry of Agriculture and Rural Development.

Supriyo H., Matsue N., Yoshinaga N., 1992. Chemistry and Mineralogy of Some Soils from Indonesia. Soil Science and Plant Nutrition 38(2), 217-225.

Suyamto H., 1998. Better Crops International 12(2), 12-13.

Tay Ninh Provincial People's Committee, 2012. Decision No.44 of Tay Ninh Provincial People's Committee.Quyet-dinh-44-2012-QD-UBND-Quyhoach-phat-trien-nong-nghiep-tinh-Tay-Ninh152762.aspx.

Zołotajkin M., Ciba J., Kluczka J., Skwira M., Smoliński A., 2011. Exchangeable and Bioavailable Aluminium in the Mountain Forest Soil of BaraniaGóra Range (Silesian Beskids, Poland). Water, Air, Soil Pollution (216), 571-580. 